\title{
Patinkin, the Cowles Commission, and the Theory of Unemployment and Aggregate Supply
}

\author{
Mauro Boianovsky \\ Universidade de Brasilia
}

\begin{abstract}
"For a long period before the writing of the first edition [of Money, Interest and Prices] I had been puzzled by the apparent contradiction between the intuitive feeling, on one hand, that there was a connection between a firm's product-output and its labor-input, and the traditional demand curve for labor, on the other hand, that did not depend explicitly on output and whose sole independent variable was the real wage rate.” (Patinkin, 1989, p. xvi)
\end{abstract}

\section{Introduction}

This paper offers an account of Don Patinkin's long time quest for an explanation of the connection between a firm's demand function for labour and its output. The task faced by Patinkin was how to make sense of an aggregate demand constraint and unemployment phenomena under the assumption that each firm is perfectly competitive (that is, it has a perfectly elastic demand for its output) and, therefore, can sell all it wants to sell at the current market price. The solution he eventually put forward in chapter XIII of his 1956 classic Money, Interest and Prices (henceforth $M I P$ ) was based on the notion that the influence of the representative firm's output on its labour input is reflected in the form of the labour demand function, which features a kink at the employment level corresponding to aggregate demand. The view that unemployment is explained by the involuntary departure of firms from their commodity supply and labour demand curves became the hallmark of Patinkin's contribution to the development of disequilibrium macroeconomics. However, he was not entirely satisfied with his suggested solution to the puzzle, since, although the kinked labour demand curve makes sense at the macroeconomic or aggregate level, its existence at the microeconomic level is incompatible with the definition of perfect competition (see Patinkin [1956] 1965, p. 323, n. 9). The way out is either to remove the perfect competition assumption (on which Patinkin did not elaborate, but mentioned briefly in the new preface to the 1989 abridged edition of $M I P$ ) or to design a model where perfectly competitive firms 
are demand-constrained in the sense that they must form expectations of market prices, a notion that can be found in print in Patinkin's $(1979,1982)$ studies of Keynes's aggregate supply function, but that can be traced back to the model put forward (and later abandoned) in the 1953 manuscript draft of MIP, held in the Patinkin archives (Special Collections Library, Duke University).

According to Patinkin's reading of Keynesian economics in the late 1940s, there was a missing piece in the unemployment literature at the time, that is, the concept of an aggregate supply function in the market for goods. This was the subject-matter of his 1949 Economic Journal article, which was the final version of earlier drafts discussed with members of the Cowles Commission for Research in Economics, among them especially Lawrence Klein, Trygve Haavelmo and Jacob Marschak, director of research of the Commission between 1943 and 1948 (see Patinkin, [1949a] 1981, p. 155). Marschak was also chairman of Patinkin's PhD thesis committee at the University of Chicago. Patinkin's doctoral dissertation "On the consistency of economic models: a theory of involuntary unemployment" was submitted in the spring of 1947. There was a common theme running through the dissertation: overdetermination and inconsistency of systems with homogeneous equations. This comes to the fore as soon as aggregate supply is introduced into the traditional Keynesian macroeconomic model. As recalled by Klein (1987, p. 352), the "Patinkin problem" was intensively discussed because of its implications for the interpretation of the simultaneous equations systems typically deployed at the Cowles Commission. ${ }^{1}$

This paper is organized as follows. The next section investigates Patinkin's first attempts (in a couple of unpublished manuscripts produced at the Cowles Commission and in the 1949 EJ article) to deal with the issues raised by the introduction of an aggregate supply function in the traditional Keynesian macro model. The crucial issue of the compatibility between Keynesian macroeconomics and perfect competition surfaced at the Commission (see Klein 1947a, Haavelmo 1949-50 and Marschak 1951, 1954) under the guise of the investigation of the consistency of macroeconomic models featuring the double determination of the level of output by the supply and demand for labour plus the production function on one side, and by aggregate demand (or the savings-investment equation as function of income) on the other. Section 2 also compares Patinkin's treatment of aggregate supply to Marschak's, who introduced the concepts of aggregate supply and demand on the price-output space in his 1951 text on macroeconomics, based on lectures given at the University of Chicago in 1948 and 1949. Marschak used his new diagram to argue that the output of firms is demand-constrained if the aggregate demand curve is not affected by the price level, which is not far from Patinkin's 1949 article. Section 3 brings out the model advanced in Patinkin's 1953 draft of ch. XIII of MIP, which differs from the published version by assuming that price expectations of the representative firm provide a bridge between its demand function for labour and its output level. Section 4 examines why Patinkin gave up the 1953 
equilibrium model and replaced it in 1956 by the notion that firms depart involuntarily from their aggregate supply curve. It is shown that Patinkin's view that the form of the labour demand equations change in the presence of unemployment was shared by Haavelmo $(1950,1954,1960)$. Section 5 brings wage determination into the picture. Patinkin did not clarify in the 1940s and 1950 s that the notion that firms are demand-constrained cannot account, under the assumption of perfect flexibility of money-wages, for excess supply in the labour market. It is necessary to introduce a Phillips curve like specification of money-wage dynamics, as pointed out by Patinkin (1974) in connection with Klein's econometric investigation of the labour market in the 1950s. Section 6 provides evidence that Patinkin eventually gave up in the late 1970s and early 1980s his claim that Keynes's (1936) presentation of the principle of effective demand was marred by the absence of disequilibrium analysis of the goods market. Section 7 concludes.

\section{Aggregate supply and overdetermination}

Although Patinkin, during his years at the Cowles Commission, did not dwell on the connection between a firm's demand function for labour and its output, the topic is implicit in his treatment of the analytical implications of the introduction of an aggregate supply function into the traditional Keynesian diagonal cross model. As discussed in this section, Patinkin ([1949] 1981) put forward two distinct concepts of aggregate supply, which he labeled "desired" and "familiar" supply functions. The starting-point for the discussion of overdetermination of homogeneous systems at the Commission was Patinkin's (1946, p. 11) "real" aggregate model of the economy:

(a) $\mathrm{X}^{\mathrm{d}}=\pi[(\mathrm{w} / \mathrm{p}) \mathrm{N}, \mathrm{Y}-(\mathrm{w} / \mathrm{p}) \mathrm{N}] \quad$ demand for goods

(b) $\mathrm{Y}=\varnothing\left(\mathrm{N}, \mathrm{K}_{\mathrm{O}}\right) \quad$ production function

(c) $\mathrm{N}^{\mathrm{D}}=\mathrm{f}\left(\mathrm{w} / \mathrm{p}, \mathrm{K}_{\mathrm{O}}\right) \quad$ demand for labour

(d) $\mathrm{N}^{\mathrm{S}}=\mathrm{g}(\mathrm{w} / \mathrm{p}) \quad$ supply of labour

(e) $\mathrm{N}^{\mathrm{D}}=\mathrm{N}^{\mathrm{S}}=\mathrm{N}$

(f) $X^{d}=Y$

which gives 7 equations [since equation (e) consists in fact of two equations] in 6 variables (Y,w/p. $\left.\mathrm{N}, \mathrm{N}^{\mathrm{D}}, \mathrm{N}^{\mathrm{S}}, \mathrm{X}^{\mathrm{d}}\right)$. The "familiar aggregate supply function" was introduced by Patinkin ([1949a] 1981, pp. 171-72) by substituting (c) into (b), that is, $\mathrm{Y}=\varnothing\left(\mathrm{N}^{\mathrm{D}}, \mathrm{K}_{\mathrm{O}}\right)$. In MIP Patinkin ([1965] 1965 , ch. IX) wrote the function explicitly as $\mathrm{Y}=\varnothing\left[\mathrm{f}\left(\mathrm{w} / \mathrm{p}, \mathrm{K}_{\mathrm{O}}\right), \mathrm{K}_{\mathrm{O}}\right]$, which gives the aggregate 
supply function $\mathrm{Y}=\mathrm{S}\left(\mathrm{w} / \mathrm{p}, \mathrm{K}_{\mathrm{O}}\right)$. As he explained in that book (p. 209), the function describes the outcome of a "conceptual individual-experiment" in which a perfectly competitive firm decides its optimum output level in order to maximize its profits based on the technology, its fixed amount of capital and the real wage rate. Despite the fact (as later acknowledged by Patinkin; see 1976, p. 84, n. 3) that a similar notion of an aggregate supply function can be found in Keynes (1936, ch. 3) under the guise of the Marshallian phrase "aggregate supply price", Patinkin's 1949 discussion was the first formal elaboration of the concept in the macroeconomic literature. ${ }^{2}$ Although the formal presentation of the aggregate supply function is the same in chapter IX of MIP and in section 14 (pp. 171-75) of the 1949 article, it should be noted that while in the book Patinkin put emphasis on the discussion of disequilibrium positions of the market for goods illustrated by points off the supply curve, in the article it is assumed that "equilibrium is rapidly restored" in the market for goods following a downward shift of aggregate expenditure, so that in periods of unemployment there is disequilibrium in the labour market only ([1949a] 1981, p. 169; Patinkin acknowledged that his presentation of the argument was influenced by discussion with Kenneth Arrow at the Cowles Commission. Workers are off their supply curve of labour, but firms are supposed to be on their demand for labour curves throughout the adjustment process.

Besides the concept of a "familiar supply function" described above, Patinkin ([1949a]1981, pp. 158-62) presented also a "desired supply function" based on the behaviour of "suppliers" as a whole understood as workers and firms together. Patinkin's "desired supply function" did not survive in the literature (except for Edwards 1959, disussed below) and it may look odd for the standard reader. As pointed out by de Jong (1954, section 2), Patinkin's "desired" function results from the substitution of labour supply [equation (d) above] into the production function (b). Differently from the "familiar function", it describes points of full-employment. That concept grew out of Patinkin's first attempts in his unpublished manuscripts of December 1946 and March 1947 to study the analytical implications of demand-constraints for the concept of involuntary unemployment. Under the assumption that there are no firms and that the economy is inhabited by workers and consumers only, Patinkin argued that involuntary unemployment should be interpreted as the manifestation of an overdetermined model where workers face a demandconstraint. Overdetermination is formally removed by showing that workers are not able anymore, under conditions of demand-constraint, to maximize their utility through the distribution of time between work and leisure. Workers are, therefore, off their supply curve of effort, which, in this economy, is formally the same as the aggregate supply function of goods. ${ }^{3}$

Patinkin (1946, p. 20) claimed that this argument shows that "the rigorous theoretical economist must adhere to the definition of unemployment as being off the supply curve of labour". This is a definition that Patinkin carried to section 8 (pp. 162-64) of the $1949 E J$ article and to 
chapter XIII (section 1) of MIP as well. However, while in MIP (p. 315) he measured involuntary unemployment as the extent of the excess supply of labour which exists at the prevailing real wage rate, in 1949 (p. 163) it is described as the difference between the market equilibrium fullemployment level (at the real wage rate determined by the intersection between the supply and demand curves for labour) and the level of employment decided by demand for labour at the current real wage rate. The better-known definition put forward in MIP is fully consistent with the reservation wage definition of involuntary unemployment usually adopted in the literature, but not the interpretation advanced in 1949, which might reflect in part the influence of discussion with Haavelmo at the Cowles Commission. 4

The 1949 definition of involuntary unemployment is consistent with Patinkin's claim that involuntary unemployment should be measured, in the diagonal cross diagram (see figure 1 below, where $\mathrm{E}$ stands for aggregate demand, and S for aggregate supply), by the difference between the level of income that "suppliers" want to produce (that is, the level of income where the "desired supply function" intersects the diagonal cross) and the actual income level (decided by the intersection between aggregate expenditure and the diagonal cross). The "desired aggregate supply function" is represented by Patinkin ([1949a]1981, fig. 6; reproduced as figure 1 below) as an almost horizontal line, which depends only slightly on income. The dependence of that function on income is a problematic element in its formal construction, since, as explained by Patinkin in footnote 5 of the 1949 article and in the mathematical appendix (excluded from the version published in $E J$, but included in the 1981 reprint), the price index used to aggregate the expenditure function (based on the price of finished goods only) must be the same one used to aggregate the supply function (based also on the price of productive services). Because of that, Patinkin is led to assume that both price indexes move proportionally, that is, a constant real wage. However, as pointed out in the 1981 reprint as an addition to footnote 5, this assumption cannot be made, since it contradicts the law of diminishing returns and, therefore, perfect competition. A correct diagrammatic derivation of Patinkin's desired aggregate supply curve was provided later on by Edgar Edwards (1959, section 6). It is represented as negatively sloped in the diagonal cross diagram, expressing the output level that would be produced by the amount of labour supplied at the real wage rate implicit at each level of output, so that its intersection with the diagonal cross defines full-employment output, as intended by Patinkin.

[insert figure 1 around here]

Patinkin (1989, p. xvi) suggested, in a passage that follows immediately the quotation reproduced at the start of this paper about the connection between the firm's output and its labour input, that the answer finally proposed in chapter XIII of MIP "in part goes back" to his 1949 EJ article. However, as discussed above, the off aggregate supply curve analysis in the first sections of 
that article refers to the full-employment "desired" function and to the application of the notion of "demand-constraints" to the supply of effort by workers. Hence, it differs from the argument of $M I P$, where firms are involuntarily off their supply curves (that is, off the "familiar aggregate supply curve", in the terminology of the 1949 article) and their labour demand curves. Nevertheless, despite the fact that Patinkin ([1949a] 1981, section 14, pp. 171-72) assumed that the employment decision of firms is based only on the current real wage rate, it is true that the solution advanced in the book is partly present in the article, in the form of the relative insensitivity of the aggregate expenditure function to changes in the price level ([1949a] 1981, section 9; see also Patinkin [1948b] 1972). The introduction of the price level as an argument in the expenditure function, in the form of real money balances, turns the homogeneous system described above into a nonhomogeneous and, therefore, a determinate and consistent one (see Patinkin's [1949b] 1981, sections 9 and 14, on a theorem on homogeneous function and on the introduction of the real balance effect). Falling prices will tend to shift the expenditure function upwards towards the fullemployment income defined by the intersection between the "desired aggregate supply curve" and the diagonal cross. Nonetheless, due to the assumed low price elasticity of aggregate demand, firms' demand for labour will remain below the full-employment level of labour supply throughout the path to aggregate equilibrium. ${ }^{5}$

We may conclude from our discussion so far of Patinkin's notions of aggregate supply in the 1940s that their role in Patinkin's framework was to express analytically the view that involuntary unemployment is necessarily accompanied by an imbalance in the labour market (which comes out directly from the notion of "desired" aggregate supply) and an ensuing downward pressure on money-wages and prices. Marschak's reaction to Patinkin's use of the concept of an aggregate supply function in his 1947 "Reconsideration of the Theory of Unemployment" is illustrative of the neglect of the supply side in Keynesian theory at the time. Marschak asked Patinkin in March of that year: "Has this concept [of a supply function] ever been used? What is its counterpart in the Keynesian system? It cannot be an investment function...nor can this be the production function, I think". Marschak's bewilderment with the aggregate supply function concept did not last long, though, for in his 1948 lectures at the University of Chicago - where he had replaced Oskar Lange as professor of macroeconomics - he was already discussing the "Supply Curve for All Goods" as a function of the price level (Marschak, 1951, lecture 19). Marschak's aggregate supply function can be interpreted as a reduced form of the "supply sub-set" of the economy formed by the structural equations of the labour market: labour demand, labour supply, equality between demand and supply in a "free" (i.e., non-unionized) labour market, and the production function. Like Patinkin's “desired supply curve", it describes points of equilibrium in the labour market, but, unlike Patinkin ([1949a]1981), Marschak did not discuss the existence of 
points off the aggregate supply curve. If both the demand and supply of labour functions were free of money illusion (that is, depend only on the ratio between money wages and prices, not on their absolute values), Marschak's aggregate supply function would be depicted as a horizontal line, with $\mathrm{p}$ and $\mathrm{Y}$ on the horizontal and vertical axes respectively. More generally, the curve is drawn as upward-sloping, reflecting the assumption that employers are "relatively more price-conscious" than the workers (Marschak, 1951, p. 59; see figure 2 below). It should be noted that money-wage flexibility assures labour market equilibrium regardless of the assumption of money illusion, which, however, is relevant for the non-neutrality of changes in money supply (see Patinkin [1956] 1965, pp. 281-85, for a similar argument).

[insert figure 2 around here]

As pointed out by George Horwich (1997, p. 8), Marschak (1951) presented the first formulation of what would become known a few decades later as the "AS-AD model". 6 Marschak's "demand curve for all goods" was advanced in lecture 18, where he developed the "demand subset" of the model. It consists of 3 equations (private aggregate demand as a function of income, interest rate, money stock and tax rate; the equality between income and the sum of private demand and government expenditure; and the equality between the money stock and money demand as a function of interest, income and the tax rate) in three endogenous variables (private aggregate demand, income and interest rate), all measured in nominal terms. He then writes $\mathrm{Y}$ as a reduced form function of all the exogenous variables of the demand sub-set and introduces the key assumption that at least one group of individuals suffers from "money illusion" in their expenditure decision (consumers or government etc), which assures that the price level enters the system of behaviour equations and, by that, brings about a negative functional relation between real income and the price level in the demand sub-set. The system formed by Marschak's equations of aggregate supply and demand will produce solutions for real income and price (that is, will not feature overdetermination) only if at least one of the sub-sets is non-homogeneous. The system will feature overdetermination if both aggregate supply and aggregate demand curves are horizontal (that is, independent of the price level), a case not depicted by Marschak in his diagrammatic illustration (see figure 2 below). Differently from Patinkin's ([1948b] 1981, section 14; MIP, ch. II) concept of a real balance effect, Marschak described the influence of the price level on aggregate demand as a case of "money illusion" and entertained the possibility of a system formed by a horizontal aggregate demand function and an upward-sloping aggregate supply function on the real income-price level space, which he called the "extreme Keynes" case (Marschak, 1951, pp. 62-63; see figure $2 \mathrm{C}$ below). ${ }^{7}$

The notion of a macroeconomic demand constraint comes out clearly under the assumption of the "extreme Keynes case" and a "free labour market" with flexible money-wages (see figure 2C 
below). In these circumstances, "real income and hence (via the production function) employment is completely determined by those [aggregate demand] decisions. The revision of workers' willingness to work, causing a shift in the SS-curve, would change the price level, but not employment. All unemployment is involuntary!” (p. 63). Also, under the further assumption that labour demand (but not labour supply) is free from money illusion, the real wage rate (equal to the marginal productivity of labour) is determined by aggregate demand and the corresponding level of employment. The causality relation between employment and the real wage rate becomes, therefore, the inverse of what is usually assumed in the microeconomic theory of the demand for labour function. Furthermore, as stressed by Marschak, the kind of involuntary unemployment generated by a horizontal aggregate demand curve (the inability of wage-cuts to raise employment) is not involuntary in the sense that not all people willing to work at existing $\mathrm{w}$ and $\mathrm{p}$ get jobs. "They all $d o$ ", since the labour market is in equilibrium with $\mathrm{N}^{\mathrm{D}}=\mathrm{N}^{\mathrm{S}}=\mathrm{N}$. This concept of involuntary unemployment is not far from Haavelmo's (1950). In order to introduce the notion of involuntary unemployment as excess labour supply it is necessary to assume some form of money-wage rigidity

and replace labour market equilibrium by the short-side rule $\mathrm{N}=\min \left(\mathrm{N}^{\mathrm{D}}, \mathrm{N}^{\mathrm{S}}\right)$, as explained by Marschak (p. 64). Hence, according to Marschak (pp. 63-64), involuntary unemployment in the first sense ("inability of wage-cuts to raise employment", which is close to ch. 19 of Keynes, 1936) should be distinguished from involuntary unemployment in the second sense ("the excess of the number of people willing to work at a given w and p over the level of employment", which is close to ch. 2 of Keynes, 1936) The application of the short-side rule to the labour market is only implicit in Patinkin's 1949 EJ article, but explicit in his last statement of the aggregate supply function (Patinkin, 1993), as discussed in section 6 below. 8

\section{Price Expectations and the Demand for Labour}

When Patinkin set off to write the first draft of MIP in Jerusalem in 1953, the 1949 ambiguous "desired-supply function" was gone, replaced by the "familiar aggregate supply function" of section 14 of that article. Correspondingly, the function is now represented in the Keynesian cross diagram by a vertical line drawn at the level of output yielded by the aggregate supply function $\mathrm{S}$ for any given real wage rate (see figure 3 below). As noticed by Dennis Robertson in correspondence of January 14, 1956 (a few months before the book came out), Patinkin's new supply function, in contrast with the 1949 "desired-supply function", does not yield a unique (full-employment) equilibrium:

I can't see what happens to your diagram now that you draw your $\mathrm{S}$ as a vertical not as a horizontal straight line. There is an infinity of such straight lines, each 
corresponding to a point on the DY axis, and I don't see how we know which to use until we have determined $\mathrm{y}$. But the determination of $\mathrm{Y}$ is the object of the exercise.

Robertson's letter was a reply to an unpublished note by Patinkin on "Keynes and Supply Functions: a Comment" written in 1955 as a reaction to de Jong (1954) and Robertson (1955). In the note (p. 3) Patinkin clarified that "I no longer consider my original graphical representation of the aggregate supply function to be correct. In particular, I would now dispense with the assumption that this function is even slightly dependent on Y. In addition, I would now represent it as a vertical line", which is the form employed in "my forthcoming" book (cf. [1956] 1965, fig. IX-3, p. 212). [insert figure 3 around here]

The relation between the redefined supply curve and the labour market during periods of unemployment is the focus of chapter IX of the 1953 draft of, the first version of chapter XIII of MIP. Patinkin had left open in his 1949 article the explanation of how aggregate demand affects the output and employment decision of firms at the microeconomic level. The issue should be understood against the background of the macroeconomic literature of the time, especially Klein and Samuelson. Patinkin referred on that occasion to the traditional argument that, if income is above its equilibrium level determined by the intersection between the expenditure function and the diagonal cross, "the resulting accumulation of undesired inventories would drive prices down and therefore discourage production". Such a dynamic analysis, however, calls into play factors outside the analytical framework of the diagonal cross and presupposes an assumption about the supply side of the market (Patinkin [1949a] 1981, pp. 158-59). The dynamic adjustment assumed by Klein both in his discussion of the diagonal cross and in his path-breaking macroeconometric model of the American economy (1947b, pp. 113-115; 1950, pp. 55-57) was the well-known mechanism of output changes induced by involuntary inventory accumulation when aggregate output differs from expenditure (or planned savings differ from planned investment). That dynamic equation had been introduced by Paul Samuelson (1941, pp. 113-120) in his macroeconomic "analysis of the Keynesian system". In contrast with his famous dynamic microeconomic equation for price changes presented in the first sections of the same article, Samuelson's macroeconomic equation assumed implicitly fixed prices and adjustment of quantities only. That dichotomy comes out clearly in Klein (1950, pp. 50-57), who applied Samuelson's dynamic equation for price changes in "competitive markets" in partial equilibrium, but assumed that for the theory of income determination a different dynamic equation where output is the adjustment variable and markets are "imperfectly competitive".

The macroeconomic dynamic adjustment mechanisms put forward by Klein and Samuelson is based on the notion that each firm faces a sales constraint and, therefore, that anticipated sales is 
an argument in the firm's demand for labour function. As Klein apparently was aware, this is inconsistent with a perfectly competitive goods market, for in such markets firms must assume that they can sell all they want to at the current market price (see also Dutt, 1987, p. 282). The issue of the compatibility between Keynesian macroeconomics and the orthodox theory of perfectly competitive markets was brought up by Richard Lester (1946) in his controversy with F. Machlup and G. Stigler over the marginalist theory of production. According to Lester (p. 63), there was "a gap between marginal theory of the firm and general theories concerning employment, money, and the business cycle...The hiatus exists in Keynes's General Theory, despite his efforts to avoid inhabiting two separate theoretical worlds. He fails to reconcile his continued adherence to the marginal productivity theory with his new theories of employment determination, based on effective demand". Lester (p. 65) concluded from his empirical investigation that the most important factor in determining the firm's volume of employment is the "current and perspective market demand for its products", instead of the real wage rate. 9

After the somewhat disappointing results of his 1949 EJ article, the 1953 draft of chapter XIII of MIP was Patinkin's first attempt to fill the gap between the traditional microeconomic theory of the firm and macroeconomic analysis. By introducing the real balance effect in the theory of demand, Patinkin ([1949b] 1981] had performed a similar task in bringing together monetary theory and the microeconomics of consumption. Patinkin kept Keynes's assumption of perfect competition in the goods market and consistently rejected the dynamic adjustment of the "familiar Keynesian analysis" of Samuelson and Klein. "The latter presents the decrease in employment as a result of the deflationary gap - the inability of firms to find buyers for the full employment output. In our model, however, anticipated sales are not one of the explicit factors which influence the demand for labour" (Patinkin, 1953, p. IX-6). Patinkin's suggested solution to the riddle was to introduce the notion that the competitive firm decided its demand for labour on the basis not of the current existing real wage rate, but of what he called "anticipated effective rate", that is, the moneywage divided by the price level expected by the representative firm. As explained by Patinkin, the implicit influence of anticipated sales "is fully reflected by an increase in the effective real wage rate. It follows that to say that firms will not be able to sell all their output is to say that this wage rate will go up, so that the employment policies of firms will be affected accordingly".

Patinkin's introduction of the concept of expected real wage rate was based on the notion that firms form adaptative expectations of the price level. Although the term itself was not used, it is clearly enough that Patinkin's competitive firms have a learning mechanism that gradually corrects their mistakes about the price level. Firms realize that they are continuously making losses when prices fall in the downswing, since "they hire labour and undertake production at one price level and sell it at a lower one". 
After this happens over a period of time, firms realize that they must plan their production on the assumption that the future price level will be lower than the present one. Correspondingly, firms will hire labour in accordance not with the existing nominal real wage rate, but with the anticipated effective rate. Thus even if the existing real wage rate remains the same, or even falls, the effective rate may rise. Hence firms will decrease the amount of labour they employ. (1953, pp. IX-5 and IX-6).

It should be noted that Patinkin, following along the lines of section 14 of his 1949 EJ article, assumes that the market for goods clears through price and output changes and, therefore, that firms are all the time on their demand curve for labour, now redefined in terms of the expected real wage rate. "It is assumed that throughout the dynamic process of adjustment the economy is to be found at a point on the demand curve for labour. Clearly, only if the economy returns to equilibrium will this also be a point on the supply curve [of labour]". (Patinkin, 1953, p. IX-4).

In one of his few articles on microeconomic theory Patinkin ([1947] 1981, p. 104) had adopted the usual description of perfect competition as an infinitely elastic demand curve at the level of the market price, so that there is an "unlimited market" for each firm. The new element added in the 1953 draft is that perfect competition does not imply perfect knowledge of the future, which is not in full agreement with the concept of perfect competition put forward by Patinkin's former Chicago teacher Frank Knight in his classic 1921 book. According to Patinkin's 1953 draft, competitive firms are uncertain of the demand they face, since they make their production and employment decisions before they know the market price. Therefore, firms in perfect competition form expectations about prices, not about their sales, since they expect to sell any amount they want to at the market price. This has been clarified in discussions about Keynes's concept of "aggregate supply price" by Victoria Chick (1983, ch. 5; 1992), Amitava Dutt (1987) and others. In particular, perfectly competitive firms are demand constrained in Keynesian macroeconomic theory in the sense that a higher aggregate demand brings about higher expected prices and induces firms to employ more labour, with the market for goods clearing in the process. This is also the interpretation that comes out of the well-known models of contractual money-wages put forward by Stanley Fischer (1977) and John Taylor (1980). ${ }^{10}$

Patinkin (1953, pp. IX-7 and IX-8) explains how, starting from a position of fullemployment, a downward shift of aggregate expenditures brings about a higher expected real wage rate and a corresponding leftward shift of the vertical aggregate supply function in the diagonal cross diagram. The process of price reduction continues until excess supply in the goods market is eliminated by the leftward movement of aggregate supply (because of higher "effective real wage 
rate") and by the upward push on the expenditure curve caused by a real balance effect in the market for goods and for bonds. When prices eventually stop falling the economy reaches an equilibrium position with expected prices equal to (stationary) current prices. This is, however, not a general equilibrium, since there is involuntary unemployment measured by excess labour supply at the current real wage rate, which exerts a downward pressure on the money-wage rate and disturbs the equilibrium previously established in the markets for goods and for bonds. The ensuing reduction in the effective real wage rate causes a rightward shift of the aggregate supply curve and, by that, a deflationary gap in the market for goods. Prices start falling again and push the expenditure curve further upwards, until a new full-employment position is reached with lower prices, money-wages and interest rate but with the same real wage rate as in the original equilibrium position. Although unemployment is described as a disequilibrium phenomenon - in the sense that there is excess supply in the labour market, that price expectations are not confirmed and that the process of changes in prices and money-wages only gradually shifts the expenditure function back it is worth noting that perfectly competitive firms are assumed to remain on their labour demand functions, an assumption that Patinkin carried from his 1949 EJ article but would remove from the printed version of the $1953 \mathrm{draft}$, as discussed in section 4 below.

There are almost no traces of the 1953 expectational model of labour demand in MIP, where stationary expectations are assumed throughout. The 1953 argument about the influence of price expectations on labour demand is only mentioned in passing, as an afterthought to the main results of chapter XIII. "The anticipation of a lower future price level has the same effects on the amount of labour demand as a rise in the current real wage rate. For, in making their plans, firms will compare the wage paid for current input with the lower price that will subsequently be received for its resulting output." ([1956] 1965, p. 337). The standard assumption about price expectations in macroeconomic models in the 1940s and early 1950s was one of "static expectations", defined by Lange (1944, p. 20) in the Cowles Commission Monograph no. 8 as the notion that "all decisions are based on the expectation that current prices will continue during that part of the future which is relevant to present decisions". It corresponds to John Hicks's ([1939] 1946) concept of "unity elasticity of expectations", which, according to Hicks, was introduced into the literature for the first time as part of Knut Wicksell's ([1898] 1936) famous "cumulative process" of price change. The assumption of "static expectations" was adopted, among others, by Modigliani (1944, p. 45) and by Patinkin himself in MIP ([1956] 1965, pp. 61, 200), where he wrote that "for simplicity, it is assumed that these future prices are expected - with certainty - to be identical with current ones". Furthermore, and more importantly for the purposes of this paper, he decided in the book to abstract from the "complications" produced by discrepancies between actual and expected prices. ${ }^{11}$ 


\section{Disequilibrium and the "form of the equations"}

Deprived of his 1953 notion of "effective real wage rate", Patinkin came back in chapter XIII of $M I P$ to the influence of anticipated sales on labour demand and aggregate supply functions. However, instead of resorting to the inclusion of expected sales as an independent variable in the labour demand function - which would be inconsistent with the assumption of perfectly competitive firms - Patinkin ([1956] 1965, p. 319) decided to capture its influence by changing the form of that function.

Our demand function for labour describes the behaviour of firms maximizing profits within a framework of perfect competition. This means that the planned labour input it specifies for any given real wage rate reflects the firms' assumptions that they will be able to sell all of their resulting output at the prevailing market price. Hence any development in the commodity market which invalidates this crucial assumption must also invalidate these plans...Thus the influence of commodity output on labour input reflects itself, not in the variables on which the labour demand function is dependent, but in its form. (italics in the original)

The upshot of this argument is Patinkin's famous kinked demand function for labour and the notion that firms are involuntarily off the aggregate supply curve during periods of unemployment. This is illustrated in figure 3, where, at the current real wage rate, the actual output of demand-constrained firms is less than the optimum (full-employment) output decided by their aggregate supply function S. As explained in sections 2 and 3 above, Patinkin's presentation of the aggregate supply function $\mathrm{S}$ in MIP is based (like the "familiar"supply function of 1949) on the substitution of the demand for labour function into the aggregate production function. Eventually, the kinked labour demand function became one of the backbones of the development of disequilibrium macroeconomics by Barro and Grossman (1971) and others, under the assumption that prices are rigid in the short run and that the short-side rule applies to the goods market. However, Patinkin's model is not a fixprice one, which has important implications for the logical consistency of his kinked demand curve. As acknowledged by Patinkin ([1956] 1965, p. 323, n. 9) in a long footnote, his suggested solution to the puzzle of the influence of the firm's output on its labour-input is beset by a "basic analytical problem". Although the kink in the labour demand curve makes sense from the viewpoint of the economy as a whole, "by definition of perfect competition this kink cannot be taken into account by any individual firm". Interestingly enough, Patinkin suggested in passing that "the development of a theory of the firm operating under conditions of uncertainty with respect to the size of its market" 
could be a possible way out of the analytical difficulty. This would bring price expectations back into the picture, just like in the 1953 draft. Indeed, some authors (see Asimakopulos, 1982, p. 32, n. 29; Dutt, 1987, p. 284, n. 16) have suggested that Patinkin's off aggregate supply curve analysis could be interpreted as the result of a difference between actual prices and expected prices, which would cause firms to leave their demand for labour curve described by the equality between the actual real wage rate and marginal productivity of labour. Alternatively, the short run labour demand function (as well the aggregate supply curve) could be defined in terms of the expected real wage rate just as in the $1953 \mathrm{draft}$, so that employment (whether at its full level or not) would remain stationary if price expectations are fulfilled. ${ }^{12}$

The notion that the form of some of the equations may change in the short run can be found in Haavelmo's (1954, p. 89) remarks that “the long-range effects of the short-run phenomena [of involuntary unemployment and overproduction] can be incorporated in the form of the functional relations considered". That suggestion was developed later on in chapter 33 of his 1960 Study in the Theory of Investment, where Haavelmo investigated the analytical consequences of the introduction of an exogenous market rate of interest into an otherwise determined "classical" system of equations. Under the assumption that the rate of interest is set by the monetary policy of the central bank of fixing the real amount of money regardless of the price level, the system becomes overdetermined (cf. Patinkin [1956] 1965, p. 309). According to Haavelmo (1960, pp. 202-03), the economy will operate under a different model that does have a solution, which may involve the breakdown of one or more classical behaviour patterns, such as the demand for labour function. If the exogenous market rate of interest is higher than the value of the endogenous interest rate that solves the original "classical" model, the ensuing falling prices will make firms "afraid of not being able to sell and start producing to order, instead of producing as if selling was no problem", which introduces a new degree of freedom (called 'production strategy') into the system and solves the overdetermination problem. Haavelmo (p. 204) suggests that the production strategy of perfectly competitive firms depends on whether they operate on the classical model without demand constraints or in the depression model. In the first ("classical") case, the producer maximizes profit for any given level of output and chooses that output which gives the largest among the relative profit maxima. In the depression case, the producer maximizes profit for an assumed given volume of output, determined by somebody else. The upshot is that "there is no reason why the form of a realistic model (the form of its equations) should be the same under all values of its variables. We must face the fact that the form of the model may have to be regarded as a function of the values of the variables involved. Thus, for example, it is obviously absurd to maintain a supply equation which presupposes free quantity adaptation to given prices if the actual market situation is characterized by selling difficulties" (p. 205). ${ }^{13}$ 
Although Haavelmo did not refer to Patinkin in that connection, his discussion of changes in the form of the labour demand function is clearly reminiscent of similar ideas advanced in 1956 in chapter XIII of MIP. As pointed out by Moene and Rodseth (1991, pp. 188-89), Haavelmo's discussion of the role of effective demand in different regimes has similarities with the disequilibrium macroeconomic literature of the late 1960s and early 1970s. However, when compared to Patinkin, Haavelmo did not draw the same implications as far as positions off the labour demand curve are concerned. In particular, his argument is not that firms operate off their classical or Walrasian demand functions for labour when they are demand-constrained, but that the classical function is replaced by another one reflecting the altered conditions of choice of producers. ${ }^{14}$ The notion that the Walrasian demand for labour function becomes overdetermined when effective demand is introduced has been discussed also by Leijonhufvud (1974, p. 167). Leijonhufvud describes chapter XIII of MIP as a "strange interlude" in the book and suggests that "Patinkin seems not to perceive [in chapter XIII of MIP] that the way in which the problem has been set up makes it overdeterminate". In a letter of February 12, 1974 to Leijonhufvud, Patinkin reacted against the description of that chapter as an interlude and pointed out that "it essentially contains the points yourself make in the paragraph in which you refer to this chapter". Instead of adopting Patinkin's kinked demand curve as a solution to the overdetermination problem, however, Leijonhufvud (p. 166) claimed that a Marshallian specification of labour demand should be used. The equality between the real wage rate and marginal productivity is a result of price competition between firms that pushes real wages until they correspond to the marginal products. While the Walrasian labour demand function is based on an individual experiment carried out under the assumption that the firm is able to sell all its output at the announced price, the Marshallian labour demand curve results from a market equilibrium condition involving price expectations of firms. Effective demand determines employment and prices adjust to clear the market for output and to generate a real wage rate equal to the marginal productivity corresponding to that employment level (see also Davidson, 1967). From that perspective, Haavelmo may be interpreted as claiming that the economy operates under a Marshallian specification of labour demand when aggregate demand constraints are present.

Patinkin's disequilibrium approach of chapter XIII might also be interpreted as a nontatonnement model, with trade at "false prices", but the evidence in support of that interpretation is not strong enough. In a short report presented at the 1947 meetings of the Econometric Society. Patinkin (1947b, p. 172) had criticized Samuelson's dynamic equation $\mathrm{dp} / \mathrm{dt}=\varnothing\left(\mathrm{X}^{\mathrm{D}}-\mathrm{X}^{\mathrm{S}}\right)$ on the grounds that the behaviour described by the equation "is not localized in any specific behaviour unit (e.g., firm) except in a few markets where there is an official auctioneer" (see also Haavelmo [1958] 1974 for a similar criticism of orthodox price theory). He elaborated the argument in his 1952 
methodological criticism of Samuelson's "correspondence principle", where he introduced the notion that there are spillover effects across markets in the determination of prices under conditions of market disequilibrium, which could restrict significantly the application of the correspondence principle to stability analysis. "The assumption that the individuals who constitute the market are able to buy or sell as much as they desire at the prevailing set of prices" is not valid and, therefore, "there are unsatisfied buyers and sellers" (Patinkin, 1952a, p. 41). However, Patinkin neither developed that criticism into a model of the determination of transactions in disequilibrium incorporating income effects (see Grossman, 1969; de Vroey, 1998, pp. 195-98) nor did he succeed in introducing dynamic elements into the static Walrasian interpretation of Keynesian macroeconomics. As suggested by Robert Clower ([1965] 1969, pp. 282-83), Patinkin's concept of "spillover effects" is unable to bring current transactions into general equilibrium theory, among other reasons because it contradicts established preference analysis by assuming that transactors alter their sale and purchase plans before prevailing market prices have changed in response to excess demand in other markets. Furthermore, from Walras's law, if spillover effects from a given market are fully reflected in other markets, effective demand in the given market is identically equal to zero, "which is to say that prices never vary" (Clower, p. 282). This helps to explain the ambiguous role played by spillover effects in the analytical structure of MIP, where Patinkin assumed (instead of establishing) that markets are stable. In particular, there are no indications that the "no false trading rule", adopted in the rest of the book, was removed from chapter XIII of MIP (as it should be, in order to account for involuntary unemployment), which accentuates the analytical contradiction between disequilibrium analysis and perfect competition, acknowledged by Patinkin himself. 15

\section{Unemployment and Wages}

Our discussion will now move back to the late 1940s and early 1950s in order to take into account the determination of money-wages, a topic that was left open at the end of section 2. As discussed above, Patinkin assumed in his 1949 EJ article that during periods of unemployment the "equilibrium in the finished goods and money markets is quickly re-established. The only pressure for continued movements of the variables comes from the failure to satisfy [the equation $\mathrm{N}^{\mathrm{D}}=$ $\left.{ }_{\mathrm{N}} \mathrm{S}\right]$ ]..the level of unemployment will continue to fluctuate as the system tries to correct the disequilibrium in the labour market" ([1949] 1981, p. 173). The same argument is found in the 1953 draft, where Patinkin assumed that money-wages are set one period in advance. The implicit assumption that wages, in contrast with prices in the markets for goods, do not quickly adjust to clear the labour market is not elaborated, though. 
In his 1948 AER article Patinkin ([1948b] 1972, p. 27, n. 34) wrote the wage adjustment equation as $\mathrm{dw} / \mathrm{dt}=\mathrm{f}\left(\mathrm{N}^{\mathrm{D}}-\mathrm{N}^{\mathrm{S}}\right)$ to indicate that money-wages are stationary only at fullemployment. A similar equation had been used by Klein (1947a, p. 116), with the proviso that the more general equation should be written as $d(w / p) / d t=f\left(N^{D}-N^{S}\right)$. As pointed out by Klein, the wage adjustment equation could be written in nominal terms only if all the other equations of the macroeconomic system are used also. Klein (1954, pp. 285-87) clarified that while the static equations of supply and demand for labour are function of $w / p$, the dynamic adjustment equation of the labour market is written as $\mathrm{dw} / \mathrm{dt}=\mathrm{f}\left(\mathrm{N}^{\mathrm{D}}-\mathrm{N}^{\mathrm{S}}\right)$. This brings out the notion that both entrepreneurs and workers are assumed to behave without money illusion in the static model, but bargaining is made in terms of money-wages reflecting a lag between price movements and wage adjustment because of contracts and information problems. Klein's dynamic wage bargaining introduces money illusion, so that "the fundamental characteristic of the system is that it contains nonhomogeneous behaviour functions when in motion but homogeneous functions in the static form" (1954, p. 286). This was Klein's solution to the overdetermination problem of Keynesian macroeconomic models at the Cowles Commission, as recalled in an interview many years later.

At the Cowles Commission we worried about the problem of homogeneous systems...we worried a lot because homogeneous functions really throw away one variable. This gave rise to the Patinkin question. The whole Patinkin problem grew out of our daily discussions at the Cowles Commission. Haavelmo, Patinkin, Rubin, Marschak, I, and others, were always around the blackboard puzzling about these issues. Haavelmo had a great idea: he said that there are systems that have a solution when they are dynamic and they are inhomogeneous, but when you stop them at a point of time and you try to take them to the steady state you force them to be homogeneous. So you say rational behaviour of an equilibrium sort has no money illusion...but the dynamic process is inhomogeneous. (Klein, 1987, pp. 351$52)^{16}$

Klein (1947a; 1947b, pp. 86 and 203) shared with Patinkin the concept of involuntary unemployment as excess labour supply at the current real wage rate. Nevertheless, apart from the brief passage from the 1948 AER article mentioned above, Patinkin did not dwell on the wage determination process until his 1974 critical comments on Milton Friedman's "Monetary Framework". According to Friedman (1974, p. 32), Keynesian models in the 1950s lacked an equation for the determination of prices, provided by the discovery of the Phillips curve. Patinkin (1974, p. 129) disagreed with Friedman's suggestion of a "missing equation" and pointed out that "even before the flourishing of the Phillips curve, Keynesian econometric models generally treated 
the wage and price level as endogenous variables of the system". He referred on that occasion to the macroeconometric estimations carried out by L. Klein and others at the Cowles Commission and after. More importantly, according to Patinkin, the concern of Keynesian econometric models with the determination of prices and wages was a by-product of their focus on disequilibrium states. "In the Keynesian system there is no equilibrium equation for the labour market, but rather a dynamic wage-adjustment equation determining the rate of change of the nominal wage rate in response to the state of excess supply in this market”. It is possible to infer from Patinkin's account that a Phillips curve like equation, with its characteristic sluggish movement of money-wages, was implicit in his own formulations in the 1940s and 1950s. Such an equation is necessary in order to turn aggregate demand constraints in the market for goods into disequilibrium in the market for labour, as suggested by Marschak (1951).

Although Klein's specification of money-wage dynamics was accepted by Patinkin, they diverged on the determination of the real-wage rate in unemployment. This is relevant for the issue of whether perfectly competitive demand-constrained firms will pay a real wage rate equal to the marginal productivity of the volume of employment on their labour demand curve (i.e., the demand price of labour), or a lower real wage rate closer to the supply price of labour (measured by the marginal disutility of that amount of labour). The answer depends not only on the equilibration of the goods market through price changes (see the reference to Leijonhufvud 1974 in section 4 above), but also on the downward pressure (if any) exerted by unemployed workers on moneywages. In his 1949 EJ article Patinkin adopted Klein's (1947b, p. 203) assumption that the market value of the real wage rate is determined by its demand price. According to Klein, "it is not meaningful to assume that employed workers move downward along their supply schedule of labour, for they would be accepting a smaller real wage than employers would be willing to pay. But it is meaningful to assume that they move upward along the demand curve for labour and get the highest possible real wage offered for the amount of labour corresponding to the reduced level of income".

Over the years, Patinkin became increasingly critical of Klein's solution to the real wage bargaining problem, which was the same one implicitly adopted by Keynes. The problem with Klein's interpretation is the tacit assumption that unemployed workers will not underbid the labour market, which contradicts his Phillips curve formulation. In an unpublished note written in the early 1990s and intended as a revision of his 1987 New Palgrave entry on Keynes, Patinkin suggested that "Keynes's basic assumption that any instant of time employed workers receive a real wage equal to their marginal product even though there are unemployed workers willing to work for less is a reflection of Marshall's fish-market analysis, in which the market price equals the demand price, even though there are sellers willing to sell for less". This was, however, an incorrect 
application of Marshall's fish-market analysis, since "in pure case there is no reservation demand there, whereas there is one in labour market, so supply curve of labour not vertical but upward sloping". On the other hand, if the concept of "constrained supply of labour" 'a la Clower, as opposed to the virtual or "notional" supply, is used, the "constrained excess demand for labour is always zero...and the [real] wage rate is, strictly speaking, then indeterminate" (letter to Tom Rymes, January 12, 1987). As pointed out by Patinkin in the same letter, this question is related to the "basic analytic problem" of footnote 9 of chapter XIII of MIP, a problem which remained unsolved.

\section{Back to Keynes?}

The publication of the first volumes of Keynes's Collected Writings in the early 1970s led Patinkin to embark on a comprehensive investigation of the development of Keynes's macroeconomic thought (see Patinkin, 1976, 1982). Chapter 9 of Patinkin (1976, p. 84, n. 3) was his first attempt to "amend [the] error" of his 1949 contention that there was no aggregate supply function in The General Theory and come to terms with Keynes's "aggregate supply price". Patinkin (1976, p. 91, n. 12; 1982, p. 131, n. 9) eventually concluded that Keynes's (implicit) formulation of the supply function was very close to Patinkin's own presentation in $M I P$, but there remained, according to Patinkin (1976, p. 94), the problem of Keynes's assumption that firms are always on the aggregate supply function. Despite the acknowledged analytical problems of chapter XIII of MIP, Patinkin referred to his claim that the traditional demand function for labour is not relevant for a situation of disequilibrium, where the assumption that firms will be able to sell all their output at the current real wage rate is not valid. 'In brief, despite Keynes' declared objective of integrating monetary and value theory, he did not really develop a theory of the demand for labour consistent with the state of unemployment qua market disequilibrium that was his major concern in the General Theory."

It is worth noting, however, that Patinkin did not repeat that piece of criticism in his 1979 and 1982 (chapter 5) studies of Keynes's theory of effective demand. Putting aside problems associated with the determination of the real wage rate under unemployment (discussed in section 5 above), Patinkin showed that Keynes's theory of effective demand has a coherent core, even if based on the assumption that firms are on their labour demand curves. In particular, he apparently gave up the view that output cannot be constrained by aggregate demand if the goods market clears through price changes. As pointed out by Patinkin (1979, p. 172; 1982, p. 126; see also Casarosa, 1981; Asimakopulos, 1982, pp. 20-21; Harcourt and O’Shaughnessy, 1985, pp. 34-35), Keynes's discussion of the theory of effective demand was marred by his modelling of the representative firm as a giant firm, representative of the economy as a whole. This caused Keynes to assume that the 
aggregate expenditure function represents entrepreneurs' expectations of demand, which is inconsistent with the Marshallian theory of firm in perfect competition. Under the assumption that the aggregate demand curve is not perceived by the representative firm, whose only relevant shortrun expectation is the price of its product, Patinkin (1979, pp. 172-73; 1982, p. 143; see also Casarosa, 1981, pp. 190-91) shows how Keynes's short-run equilibrium is determined through changes in prices and production. ${ }^{17}$ If, say, actual aggregate proceeds are in excess of the aggregate supply price expected by the representative firm (meaning that unitary demand price is higher than marginal cost), the firm will expand output until aggregate demand and supply are equal, which is the point of maximum profits and, therefore, of short-run equilibrium. This is very close to Patinkin's argument in the 1953 draft about the determination of equilibrium when short-run expectations are fulfilled. Furthermore - under the assumption that wage reductions cause "adverse expectations" just able to prevent an eventual reduction in the money-wage rate from having any net effect on aggregate demand - Patinkin (1982, pp. 141-42) explains Keynes's (1936, p. 30) statement that aggregate demand determines employment and that "the volume of employment is uniquely related to a given level of real wages - not the other way around". A fall in money-wages, given the price expectations of firms, will raise employment and output and therefore reduce the market price because of excess aggregate supply; price expectation of firms will be revised downward, which will bring the economy back to its initial equilibrium, with the same real-wage rate and employment.

Despite the formal correctness of the rectified Keynesian model of aggregate supply and its similarity to the pre-MIP formulation of 1953, Patinkin did not indicate that it could replace the problematic off labour demand function analysis of chapter XIII of MIP. Nevertheless, in his last presentation of aggregate supply, as part of the appendix to an article on Israel's stabilization program of 1985 (Patinkin, 1993, pp. 122-23), off aggregate supply analysis is conspicuous by its absence. The 1993 model is formally similar to the one presented in ch. X of MIP, with the crucial difference that output is an endogenous variable, in contrast with the full-employment model of that chapter. Patinkin's 1993 model reads (excluding the equation for foreign exchange):

$$
\begin{gathered}
\mathrm{F}(\mathrm{Y}, \mathrm{r}, \mathrm{M} / \mathrm{P})-\mathrm{Y}=0 \\
\mathrm{~N}^{\mathrm{d}}\left(\mathrm{w} / \mathrm{p}, \mathrm{K}_{\mathrm{O}}\right)-\mathrm{N}^{\mathrm{S}}(\mathrm{w} / \mathrm{p})=0 \\
\mathrm{~B}(\mathrm{Y}, \mathrm{r}, \mathrm{M} / \mathrm{p})=0 \\
\mathrm{~L}(\mathrm{Y}, \mathrm{R}, \mathrm{M} / \mathrm{p})-\mathrm{M} / \mathrm{p}=0 \\
\mathrm{Y}=\varnothing\left[\mathrm{N}^{\bullet}\left(\mathrm{w} / \mathrm{p}, \mathrm{K}_{\mathrm{O}}\right)\right]
\end{gathered}
$$

where $ø\left[\right.$ ] is the production function and $\mathrm{N}^{\bullet}\left(\right.$ ) is "the lesser of $\mathrm{N}^{\mathrm{d}}\left(\mathrm{)}\right.$ ) and $\mathrm{N}^{\mathrm{S}}(\mathrm{)})$." The equation for $\mathrm{Y}$ is the new-comer in the model, since it differs from the previous supply equation adopted in MIP 
by including explicitly Marschak's "short-side" rule in the labour market. In contrast with the off aggregate supply curve analysis of ch. XIII, the new equation states that firms will be on their labour demand curves under conditions of excess supply in the labour market.

However, the 1993 system shares with the rectified Keynesian model the implication that real wages move contracyclically, which goes against the empirical evidence and against Patinkin's ([1956] 1965, p. 324) requirement that an unemployment model should be consistent with the notion that a reduction in aggregate demand can generate a decrease in employment without requiring a prior increase in the real wage rate. From this perspective, it is hardly surprising that Patinkin (1989, p. xix) would suggest in the preface to the abridged edition of MIP that the assumption of imperfect competition in the goods market - together with some theory consistent with the constancy of real wages over the business cycle, such as efficiency-wage or insideroutsider models - should solve the analytical problems of chapter XIII and accord with the view that employment is determined by aggregate demand. Although this might be interpreted as a sad ending to Patinkin's long quest for a correct specification of the labour demand function of perfectly competitive firms, it can also be seen as an expression of his concern with the empirical basis of economic models, a methodological standpoint that originated in his years at the Cowles Commission in Chicago.

\section{Conclusion}

Our investigation of Patinkin's quest for an explanation of the notion of demand-constraint under perfect competition has shown that his interpretation changed through time. In fact, as discussed above, the notion that unemployment is accompanied by equilibrium in the market for goods (in contrast with the better-known approach of ch. XIII of MIP) is clear enough in Patinkin's 1949 Economic Journal article and in its earlier drafts produced between 1946 and 1948 at the Cowles Commission. According to Patinkin ([1949a] 1981, pp. 164-68), firms are demand-constrained to the extent that a reduction of the price level, caused by excess aggregate supply, has a small or zero effect on aggregate expenditure. Even if the economy eventually converges to its full-employment level through the operation of the real balance effect, it will feature unemployment throughout such a time-consuming process. Patinkin did not clarify on that occasion, however, the mechanism explaining how perfectly competitive firms' decision to demand labour is influenced by aggregate demand. His first answer to the puzzle was advanced in the 1953 draft, where Patinkin pointed out that it is through the price expectations of firms that aggregate demand can indirectly affect their expected real wage rate and, by that, their employment decision, which, in contrast with the treatment in the printed version, is depicted by a point on the labour demand function. This is close 
to the Keynesian interpretation (both in its post-Keynesian and new Keynesian versions) available in macroeconomic textbooks nowadays.

Patinkin's expectational model of 1953 did not survive in the published version of MIP, though, where he introduced instead the idea that involuntary unemployment co-exists with rationing in the labour and goods markets. The disequilibrium approach of 1956 reflected Patinkin's attempt to link the working of a labour market in the Marshallian/Keynesian tradition with perfectly competitive goods markets in the Walrasian tradition, where the notion of sales expectations is conspicuously absent. Nevertheless, ch. XIII of MIP is beset by analytical difficulties, caused mainly by the inconsistency between Patinkin's disequilibrium approach and his assumption of perfect flexibility of prices under perfect competition. Patinkin acknowledged that basic analytical problem not only in footnote 9 to ch. XIII of MIP, but in other occasions as well (see, e.g., his 1987 entry on Walras's law and the 1989 preface, p. xviii). In the late 1970s and early 1980s, as part of his careful reconstruction of the analytical foundations of Keynes's notion of aggregate supply, Patinkin put forward a Marshallian intepretation of the behaviour of demand-constrained firms which, in contrast with MIP and in agreement with The General Theory, did not feature disequilibrium in the market for goods.

The development of Patinkin's thinking on unemployment and effective demand should be interpreted against the background of similar ideas produced over the time by his former colleagues at the Cowles Commission. Marschak shared Patinkin's concern with the analytical implications of the explicit introduction of an aggregate supply function into the traditional Keynesian macro model. However, Marschak moved away from Patinkin's 1949 problematic “desired supply function" and conceived of an aggregate supply function on the price level-output space, which is closer to the concept used in textbooks nowadays. Just like Patinkin, Marschak associated the notion of demand-constraint to the degree of sensitivity of aggregate demand to changes in the price level. Moreover, Marschak clarified that the notion of demand-constraint is a necessary but not sufficient condition for the explanation of involuntary unemployment as labour market disequilibrium. In the process, he introduced the short-side rule for the labour market. The crucial issue of the dynamics of money-wage determination was tackled by Klein in the context of the Commission, as recalled by Patinkin in the early 1970s. Neither Marschak nor Klein entertained the disequilibrium approach advanced by Patinkin in 1956. It was Haavelmo, as part of his investigations of the relation between involuntary unemployment and overdetermination, who came closer to Patinkin's view that the some of the equations of the orthodox neoclassical model change their form when demand-constraints are taken into account. However, instead of Patinkin's off aggregate supply analysis, Haavelmo suggested that the objective function of firms change according to the different regimes assumed. Like Patinkin's, many of the contributions of the 
Cowles Commission economists to the macroeconomic literature resulted from attempts to solve the puzzles posed by the specification of the behaviour of suppliers (firms and workers) in the Keynesian macroeconomic models of the 1940s and 1950s.

$\underline{\text { Notes }}$

I would like to thank the staff of the Special Collections Library of Duke University for their kind help with the Patinkin files and for permission to quote from the manuscripts. I am indebted to Geoff Harcourt, Hans-Michael Trautwein and participants at the "Patinkin Conference" (Lausanne, 20-22 September 2001) for helpful comments on an earlier draft. This paper was partly written during a visit to the University of Antwerp. I am grateful to the department of economics of that university and to my host Guido Erreygers. Financial support from CNPq (Brazilian Research Council) is gratefully acknowledged.

1. On the Cowles Commission econometric approach in the 1940s and 1950s see Epstein (1987) and Christ (1994). As recalled by Klein (1991, pp. 109-10), Patinkin was originally assigned by Marschak to work on a sectoral econometric model for manufacturing (see also Patinkin, 1995, p. 379). The final report was never published, probably due to his criticism of the lack of criteria to choose from multiple hypothesis. In a preliminary report of 27 February 1948 Patinkin wrote that "I have no idea of the magnitude of the confidence intervals for the parameters estimated...To handle this type of problem we must have a much further developed theory of multiple hypothesis" (quoted by Epstein, p. 106). He did not believe that the Cowles Commission's careful estimation of structural equations based on firm probabilistic principles yielded more accurate predictions than other methods and was in general skeptical about the ability of econometricians to derive empirical macroeconomic structural relations "which will stand up under the test of time" (Patinkin, 1995, p. $387)$.

2. On the early history of the Keynesian aggregate supply function see King (1994). In contrast with Patinkin's articles on monetary theory published in 1948 and 1949 in Econometrica, his 1949 $E J$ piece on aggregate supply did not cause strong reactions, except for de Jong (1954), followed by a controversy in the pages of the Economic Journal (with Ralph Hawtrey and Dennis Robertson) in which Patinkin did not participate.

3. Apparently, the first diagrammatic analysis of involuntary unemployment as points off the labour supply curve was advanced by Joan Robinson (1937; see Boianovsky, 2000). Patinkin's standard model in his unpublished essays of 1946 and 1947 consists of an economy with three commodities: labour, claims to labour (i.e. money) and leisure, all measured in terms of hours. The variables are $\mathrm{X}^{\mathrm{d}}$ (demand for labour hours), $\mathrm{X}^{\mathrm{s}}$ (supply of labour hours), S (savings), T (leisure), Y (national 
income) and the Lagrange multiplier. The individuals (who are at the same time workers and consumers) maximize the utility function $\mathrm{u}\left(\mathrm{X}^{\mathrm{d}}, \mathrm{S}, \mathrm{T}\right)$ subject to the budget restraint $\mathrm{X}^{\mathrm{d}}+\mathrm{S}=\mathrm{X}^{\mathrm{S}}=$ $\mathrm{K}-\mathrm{T}$, where $\mathrm{K}$ is the total number of hours in the period under discussion, that is, $\mathrm{X}^{\mathrm{S}}+\mathrm{T}=\mathrm{K}$. Further to those two equations, the model provides three equations describing the equality between the marginal utility of the variables in the utility function and the Lagrange multiplier, plus two definitions of national income $\mathrm{Y}=\mathrm{X}^{\mathrm{d}}$ and $\mathrm{Y}=\mathrm{X}^{\mathrm{s}}$. The system is, therefore, overdetermined, since there are 7 equations and 6 variables. He also discussed a model with firms and suggested that the determination of the actual level of employment in the presence of aggregate demand constraints depends on the relative "bargaining power" of firms and workers. As documented by Rubin (2001), Patinkin's 1946 "theory of compromise" was strongly criticized at the Cowles Commission. In this context, it should be noted that Marschak's 1951 short-side rule for the labour market can be seen as a solution to the problem posed by Patinkin.

4. See de Vroey's (1998, pp. 179-88) distinction between the "reservation wage" (non-market clearing) and the "dominated market-clearing" definitions of involuntary unemployment. In this case, "the means of endogenously reaching some welfare-dominating higher level of unemployment are lacking", an idea that de Vroey traces back to Haavelmo (1950). As claimed by Haavelmo (p. 1), the notion of involuntary economic decisions must be derived from a comparison between alternative economic models. See also note 14 below.

5. See Patinkin ([1948b] 1972, p. 19) on the empirical evidence that the effect of real balances on consumption is weak but positive. It should be noted that, from the point of view of the operation of the real balance effect, it is changes in money-wages and the price level that matter, not in the realwage rate. Patinkin (p. 17) clarified that in a criticism of A.C. Pigou, who had not made clear that "unemployment can be eliminated even if real wages remain the same or even rise...for in any case the effect of increased real value of cash balances is still present".

6. On the early history of the AS-AD model see Barens (2000). As shown by Barens, Marschak's 1951 formulation of the $\mathrm{AD}$ curve was not beset by the commodity market equilibrium inconsistency involved in the usual textbook derivation of that curve, since it was not derived from supply and demand equilibrium in the IS-LM diagram.

7. According to Patinkin ([1956] 1965, pp. 178-79), under the assumption of an "exchange economy" (i.e., without production), the price level is undetermined if there is no real balance effect. Differently from Marschak, Patinkin interpreted the influence of the price level on aggregate expenditure as a corollary of economic rationality instead of "money illusion". Patinkin (p. 211) discussed briefly the positive slope of his aggregate supply curve on a price-output space (drawn for a given money-wage) and the negative slope of the aggregate demand curve (for a given level of income and interest). As pointed out by Patinkin (p. 210, n. 7), the real balance effect could also be 
an argument in the functions of demand and supply of labour and, consequently, in the aggregate supply function. See also Marschak's 1954 detailed discussion of how to render the economic system determinate under several different assumptions about the goods and labour market.

8. In his assessment of the Cowles Commission's contributions to macroeconomics during its Chicago period, Solow (1983) described Marschak's macroeconomic lectures as "not inspired". Given Marschak's insights into the AS-AD model and the short-side rule, Solow's judgment is hardly acceptable. According to Solow, macroeconomic theory at Cowles at the time was based on personal achievements (such as the Lange-Patinkin line on the relation between the monetary and the real sectors, and Klein's macroeconometrics), not on the development of a collective tradition in macroeconomics distinct from what was going on in other places. Solow, however, left out of his account issues such as the interpretation of overdetermined systems and the analytical foundations of the notion of involuntary unemployment, which attracted more attention at the Commission than elsewhere. Generaly speaking, as suggested by Roy Weintraub (1979, ch. 4), the "neo-Walrasian" synthesis carried out by Lange, Klein, Patinkin and others at Cowles should be seen as an early contribution to the microfoundations of macroeconomics, based on Hicks ([1939] 1946) and Samuelson (1941).

9. In correspondence of February 4, 1950 to Milton Friedman, Patinkin complained that "Machlup and Stigler dispense with [Lester's empirical] findings much too glibly" and that they do not clarify "under what circumstances" they would reject the marginal productivity theory (quoted by Leeson, 1998, p. 443).

10. See Blanchard and Fischer (1989, pp. 518-19), where the money-wage is set to equalize the rationally expected labour demand and labour supply in the next period, and employment, determined by labour demand, depends on unexpected movements in the price level. See also Mankiw, 1992, chapter 11. Patinkin (1953) is silent about the price expectations of workers; it is only implicit that they do not differ from the firms' expectations and that workers agree to supply the amount of labour demanded by firms at the contracted money-wage rate. Patinkin's (1953) argument is somewhat reminiscent of Wicksell's cumulative process of price change (cf. Patinkin, 1952b; on Wicksell's influence on Patinkin's monetary thought see Boianovsky, 1998).

11. Patinkin was aware that "what we disregard here as 'complications' forms the basis of Hick's dynamic analysis" of temporary equilibrium, but defended the abstraction on the grounds that it would allow a "dynamic analysis" of the stability of the market process of the kind set off by L. Walras and P.A. Samuelson and "taken for granted" by Hicks (MIP, p. 67; cf. E.R. Weintraub, 1979, ch. 4). As pointed out by Fischer (1993, p. 20), Patinkin deployed in MIP "atemporal stability analysis" to examine the forces bringing the economy into equilibrium within each week, which differs not only form the more recent modelling practice but also from the Wicksellian 
tradition of Hicks and others.

12. Keynes's (1936, ch. 5) usually assumed that the firms' short-run price expectations are confirmed, which simplified his presentation of the theory of effective demand, but robbed his model of an explanation of the dynamic convergence to short-run equilibrium.

13. On the other hand, If the value of the market rate of interest is below its equilibrium or endogenous level, a Wicksellian upward cumulative process of price change is the consequence. The system has a dynamic solution, but not a stationary one (Haavelmo, 1960, p. 207).

14. Haavelmo (1960, p. 203) rejected the interpretation of the supply function of labour as an expression of "what workers want to do, but they cannot do". Hence, he did not accept the notion of involuntary unemployment as a position off the labour supply curve (see also Haavelmo, 1950, and note 4 above). He was aware that the breakdown of the classical labour demand function is not enough to generate the economic facts of the depression, such as low employment and low real real wages. It would be necessary to change the assumption that capital and labour are substitutes and that labour supply is an increasing function of the real wage rate (1960, p. 206). Furthermore, it is possible that Patinkin's reference to the the "form" of economic functions is a reflection of discussion with Haavelmo at the Cowles Commission in the 1940s. This is, however, unlikely, since there is no mention of that kind of argument in Haavelmo's treatments of involuntary unemployment at the time (see Haavelmo, 1949-50, p. 79, n. 1; 1950, p. 4).

15. Gogerty and Winston (1964) suggested that Patinkin's disequilibrium analysis could be rescued by the introduction of monopolistic competition behaviour during the process of price change. Following Arrow (1959), they pointed out that the assumption of perfect competition and infinitely elastic demand curves is only valid in equilibrium. Patinkin (1989, p. xvi) eventually accepted imperfect competition as a way out of the analytical problems of chapter XIII, but without referring to the non-tatonnement approach of Arrow in disequilibrium. See also Grandmont (1989, pp. 27375) on the development of disequilibrium macroeconomic models under conditions of monopolistic competition in the 1970 s.

16. "Consider a dynamic economic system which is such that, if we omitted all the dynamic elements in it, we should have an overdetermined static system. Then the dynamic system may have a solution, but it can have no stationary solution. The economic interpretation of this is that the time-motion of prices and quantities may serve as an outlet for the forces that press for the fulfilment of the impossible conditions for stationariness" (Haavelmo, 1960, p. 207). See also Haavelmo (1951), where these ideas were apparently formulated for the first time.

17. In the following, all aggregates are measured in wage units, as in Keynes (1936, ch. 3). As explained by Patinkin (1979, pp. 158-60; see also Casarosa, 1981), the production function $\mathrm{Y}=$ $\varnothing(\mathrm{N})$ in wage units is given by $\mathrm{Y}_{\mathrm{W}}=[\mathrm{p} \varnothing(\mathrm{N}) / \mathrm{w}]$. Upon substitution from the profit maximizing 
condition $\mathrm{w} / \mathrm{p}=\varnothing^{\prime}(\mathrm{N}), \mathrm{Y}_{\mathrm{W}}$ becomes the aggregate supply function $\mathrm{Z}_{\mathrm{W}}=\left[\varnothing(\mathrm{N}) / \varnothing^{\prime}(\mathrm{N})\right]$, with $\mathrm{dZ}_{\mathrm{W}} / \mathrm{dN}>1$, since $\varnothing^{\prime \prime}(\mathrm{N})<0$. Apparently, Klein (1947, p. 203) was the first one to derive the expression above for $\mathrm{Z}_{\mathrm{W}}$, but he did not develop its mathematical properties.

\section{$\underline{\text { References }}$}

\section{Archive Sources}

Patinkin, D. 1946. Unemployment in Keynesian Systems. Unpublished manuscript. Special Collections Library, Duke University.

Patinkin, D. 1947. A Reconsideration of the Theory of Unemployment. Unpublished manuscript. Special Collections Library, Duke University.

Patinkin, D. 1948. Inconsistent Systems and Involuntary Unemployment. Unpublished manuscript. Special Collections Library, Duke University.

Patinkin, D. 1953. Monetary Theory Under the Assumption of Unemployment. Unpublished manuscript. Special Collections Library, Duke University.

Patinkin, D. 1955. Keynes and Supply Functions: A Comment. Unpublished manuscript. Special Collections Library, Duke University.

Patinkin, D. 1955. Correspondence with Dennis Robertson. Trinity College, Cambridge University. Patinkin, D. 1974. Correspondence with Axel Leijonhufvud. Special Collections Library, Duke University.

Patinkin, D. 1987. Correspondence with Tom Rymes. Special Collections Library, Duke University.

\section{Other Sources}

Arrow, K.J. 1959. Towards a Theory of Price Adjustment. In M. Abramovitz (ed). The Allocation of Economic Resources. Palo Alto: Stanford University Press.

Asimakopulos, A. 1982. Keynes' Theory of Effective Demand Revisited. Australian Economic Papers. 21 (Jun): 18-36.

Barens, I. 2000. Born under a Bad Sign: The Origin and Early History of AS-AD. Unpublished manuscript. University of Darmstadt.

Barro, R.J. and H. Grossman. 1971. A General Disequilibrium Model of Income and Employment. American Economic Review. 61 (1): 82-93.

Blanchard, O.J. and S. Fischer. 1989. Lectures on Macroeconomics. Cambridge, Mass.: MIT Press.

Boianovsky, M. 1998. Real balances, the Price level and the Unit of Account: From Wicksell to Patinkin and Beyond. American Journal of Economics and Sociology. 57 (4): 579-612.

Boianovsky, M. 2000. Some Cambridge Reactions to The General Theory: David Champernowne and Joan Robinson on Full Employment. University of Hohenheim, Department of Economics. Working Paper 15/2000.

Casarosa, C. 1981. The Microfoundations of Keynes's Aggregate Supply and Expected Demand Analysis. Economic Journal. 91 (March): 188-94.

Chick, V. 1983. Macroeconomics After Keynes. Cambridge, Mass.: MIT Press.

Chick, V. 1992. The Small Firm under Uncetainty: A Puzzle of the General Theory. In B. Gerrad and J. Hillard (eds). The Philosophy and Economics of J. M. Keynes. Aldershot: Edward Elgar.

Christ, C.F. 1994. The Cowles Commission's Contributions to Econometrics at Chicago, 19391945. Journal of Economic Literature. 32 (Mar): 30-59.

Clower, R.W. [1965] 1969. The Keynesian Counter-Revolution: A Theoretical Appraisal. In R.W. Clower (ed). Monetary Theory - Selected Readings Harmondsworth: Penguin, ch. 19..

Davidson, P. 1967. A Keynesian View of Patinkin's Theory of Employment. Economic Journal. 77 (Sept): 559-78.

de Jong, F.J. 1954. Supply Functions in Keynesian Economics. Economic Journal. 64 (March): 3- 
24.

de Vroey, M. 1998. Accounting for Involuntary Unemployment in Neoclassical Theory: Some Lessons from Sixty Years of Uphill Struggle. In R. Backhouse et al (eds). Economics and Methodology: Crossing Boundaries. London: Macmillan, ch. 4.

Dutt, A.K. 1987. Keynes with a Perfectly Competitive Goods Market. Australian Economic Papers. 26 (Dec): 275-93.

Edwards, E. 1959. Classical and Keynesian Employment Theories: A Reconcilliation. Quarterly Journal of Economics. 73 (3): 407-28.

Epstein, R.J. 1987. A History of Econometrics. Amsterdam: North-Holland.

Fischer, S. 1977. Long-Term Contracts, Rational Expectations and the Optimal Money Supply Rule. Journal of Political Economy. 85 (Feb): 191-206.

Fischer, S. 1993. Money, Interest, and Prices. In H. Barkai, S. Fischer and N. Liviatan (eds). Monetary Theory and Thought: Essays in Honour of Don Patinkin. London: Macmillan, ch. 2.

Gogerty, D. and G. Winston. 1964. Patinkin, Perfect Competition, and Unemployment Disequilibria. Review of Economic Studies. 31 (1): 121-26.

Grandmont, J.-M. 1989. Keynesian Issues and Economic Theory. Scandinavian Journal of Economics. 91 (2): 265-93.

Grossman, H. 1969. Theories of Markets Without Recontracting. Journal of Economic Theory. 1 (4): 476-79.

Haavelmo, T. 1949-50. A Note on the Theory of Investment. Review of Economic Studies. 14 (1):

78-81.

Haavelmo, T. 1954. A Study in the Theory of Evolution. Amsterdam: North-Holland.

Haavelmo, T. 1950. The Notion of Involuntary Economic Decisions. Econometrica. 18 (1): 1-8.

Haavelmo, T. 1951. The Notion of Price Homogeneity. In Festskrift till Professor Dr Polit. Jorgen Pedersen. Aarhus: Universitetsforlaget, pp. 72-79.

Haavelmo, T. [1958] 1974. What Can Static Equilibrium Models Tell Us? Economic Inquiry. 12 (1): 27-34. Translated by A. Leijonhufvud.

Haavelmo, T. 1960. A Study in the Theory of Investment. Chicago: University of Chicago Press.

Harcourt, G.C. and T.J. O’Shaughnessy. 1985. Keynes's Unemployment Equilibrium: Some Insights from Joan Robinson, Piero Sraffa and Richard Kahn. In G. C. Harcourt (ed). Keynes and His Contemporaries. London: Macmillan.

Hicks, J. [1939] 1946. Value and Capital. Oxford: Oxford University Press.

Horwich, G. 1997. Aggregate Supply and Demand. In D. Glasner (ed). Business Cycles and Depressions - An Encyclopedia. New York: Garland, pp. 7-12.

Keynes, J.M. 1936. The General Theory of Employment, Interest and Money. London: Macmillan.

King, J.E. 1994. Aggregate Supply and demand Analysis Since Keynes: A Partial History. Journal of Post-Keynesian Economics. 17 (1): 3-31.

Klein, L.R. 1947a. Theories of Effective Demand and Employment. Journal of Political Economy. 55 (Apr): 108-31.

Klein, L.R. 1947b. The Keynesian Revolution. New York: Macmillan.

Klein, L.R. 1950. Economic Fluctuations in the United States 1921-41. New York: John Wiley \& Sons.

Klein, L.R. 1954. The Empirical Foundations of Keynesian Economics. In K. Kurihara (ed). Post Keynesian Economics. New Brunswick, NJ: Rutgers University Press, ch. 11.

Klein, L.R. [1964] 1966. The Keynesian Revolution Revisited. In The Keynesian Revolution. New York: Macmillan, 2nd edition.

Klein, L.R. 1987. Interaction Between General Equilibrium and Macroeconomics: An Interview. In G. Feiwel (ed). Arrow and the Ascent of Modern Economic Theory. New York: New York University Press, ch. 9.

Klein, L.R. 1991. Econometric Contributions of the Cowles Commission, 1944-47: A Retrospective View. Banca Nazionale del Lavoro Quarterly Review. No. 177, June: 107-17.

Lange, O. 1944. Price Flexibility and Employment. Bloomington, Indiana: Principia Press.

Leeson, R. 1998. The Early Patinkin-Friedman Correspondence. Journal of the History of 
Economic Thought. 20 (4): 433-48.

Leijonhufvud, A. 1974. Keynes' Employment Function. History of Political Economy. 6 (1): 16470 .

Lester, R.A. 1946. Shortcomings of Marginal Analysis for Wage-Employment Problems. American Economic Review. 36 (1): 63-82.

Mankiw, N.G. 1992. Macroeconomics. New York: Worth Publishers.

Marschak, J. 1951. Income, Employment, and the Price Level. New York: A.M. Kelley. Edited by D. Fand and H. Markowitz.

Marschak, J. [1954] 1974. Monnaie et Liquidite dans les Modeles Macroeconomiques et Microeconomiques. In J. Marschak. Economic Information, Decision, and Prediction - Selected Essays, vol. 3, ch. 40. Boston: D. Reidel.

Modigliani, F. 1944. Liquidity Preference and the Theory of Interest and Money. Econometrica. 12 (1): 44-88.

Moene, K. and A. Rodseth. 1991. Nobel Laureate - Tryvge Haavelmo. Journal of Economic Perspectives. 5 (3): 175-192.

Patinkin, D. [1947] 1981. Multiple-Plant Firms, Cartels and Inperfect Competition. In Patinkin 1981, ch. 4.

Patinkin, D. 1947. Market-adjusting and inventory equations. Econometrica. 15 (April): 172-73.

Patinkin, D. 1948a. Relative prices, Say's Law and the demand for money. Econometrica. 16 (April): 135-54.

Patinkin, D. 1948b. Price Flexibility and Full Employment. American Economic Review. 38 (Sept): 543-64. As reprinted in Patinkin 1972, ch.2.

Patinkin, D. [1949a] 1981. Involuntary Unemployment and the Keynesian Supply Function. Economic Journal. 59 (Sept): 360-83. As reprinted in Patinkin 1981, ch. 7.

Patinkin, D. [1949b] 1981. The Indeterminacy of Absolute Prices in Classical Economic Theory. Econometrica. 17 (Jan): 1-27. As reprinted in Patinkin 1981, ch. 5.

Patinkin, D. 1952a. The Limitations of Samuelson's "Correspondence Principle". Metroeconomica. 4 (Aug): 37-43.

Patinkin, D. 1952b. Wicksell's "Cumulative Process". Economic Journal. 62 (Dec): 835-47.

Patinkin, D. 1956. Money, Interest, and Prices: An Integration of Monetary and Value Theory.

Evanston: Row, Peterson.

Patinkin, D. [1956] 1965. Money, Interest, and Prices: An Integration of Monetary and Value Theory. 2nd edition. New York: Harper and Row.

Patinkin, D. 1972. Studies in Monetary Economics. New York: Harper and Row.

Patinkin, D. 1974. Friedman on the Quantity Theory and Keynesian Economics. In R. Gordon, ed. 1974, 111-31.

Patinkin, D. 1976. Keynes' Monetary Thought - A Study of its development. History of Political Economy. 8 (Spring): 1-150.

Patinkin, D. 1979. A Study of Keynes' Theory of Effective Demand. Economic Inquiry. 17 (April): 155-76.

Patinkin, D. 1981. Essays On and In the Chicago Tradition. Durham, NC: Duke University Press.

Patinkin, D. 1982. Anticipations of the General Theory? And other essays on Keynes. Oxford: Basil

Blackwell.

Patinkin, D. 1987. Walras's Law. In J Eatwell et al, eds. The New Palgrave - A Dictionary of Economics. Vol. 4: 863-868. London: Macmillan.

Patinkin, D. 1989. Money, Interest, and Prices: An Integration of Monetary and Value Theory. 2nd. edition, abridged, with a new Introduction. Cambridge, Mass.: MIT Press.

Patinkin, D. 1993. Israel's Stabilization Program of 1985, Or Some Simple Thruths of Monetary Theory. Journal of Economic Perspectives. 7 (Spring): 103-28.

Patinkin, D. 1995. The Training of an Economist. Banca Nazionale del Lavoro Quarterly Review. No. 195 (Dec): 359-95.

Robinson, J. 1937. Essays in the Theory of Employment. London: Macmillan.

Rubin, G. 2001. From Equilibrium to Disequilibrium: The Genesis of Don Patinkin's Interpretation 
of Keynesian Theory. Paper presented at the "Patinkin Conference", Lausanne, September 2001.

Samuelson, P.A. 1941. The Stability of Equilibrium: Comparative Statics and Dynamics. Econometrica. 9 (2): 97-120.

Solow, R.M. 1983. Cowles and the Tradition of Macroeconomics. In A. Klevorick (ed). Cowles Fiftieth Anniversary Volume. New Haven: Yale University Press, ch. 4.

Taylor, J. B. 1980. Aggregate Dynamics and Staggered Contracts. Journal of Political Economy. 88 (Feb): 1-23.

Weintraub, E.R. 1979. Microfoundations. Cambridge: Cambridge University Press.

Wicksell, K. [1898] 1936. Interest and Prices. London: Macmillan. 


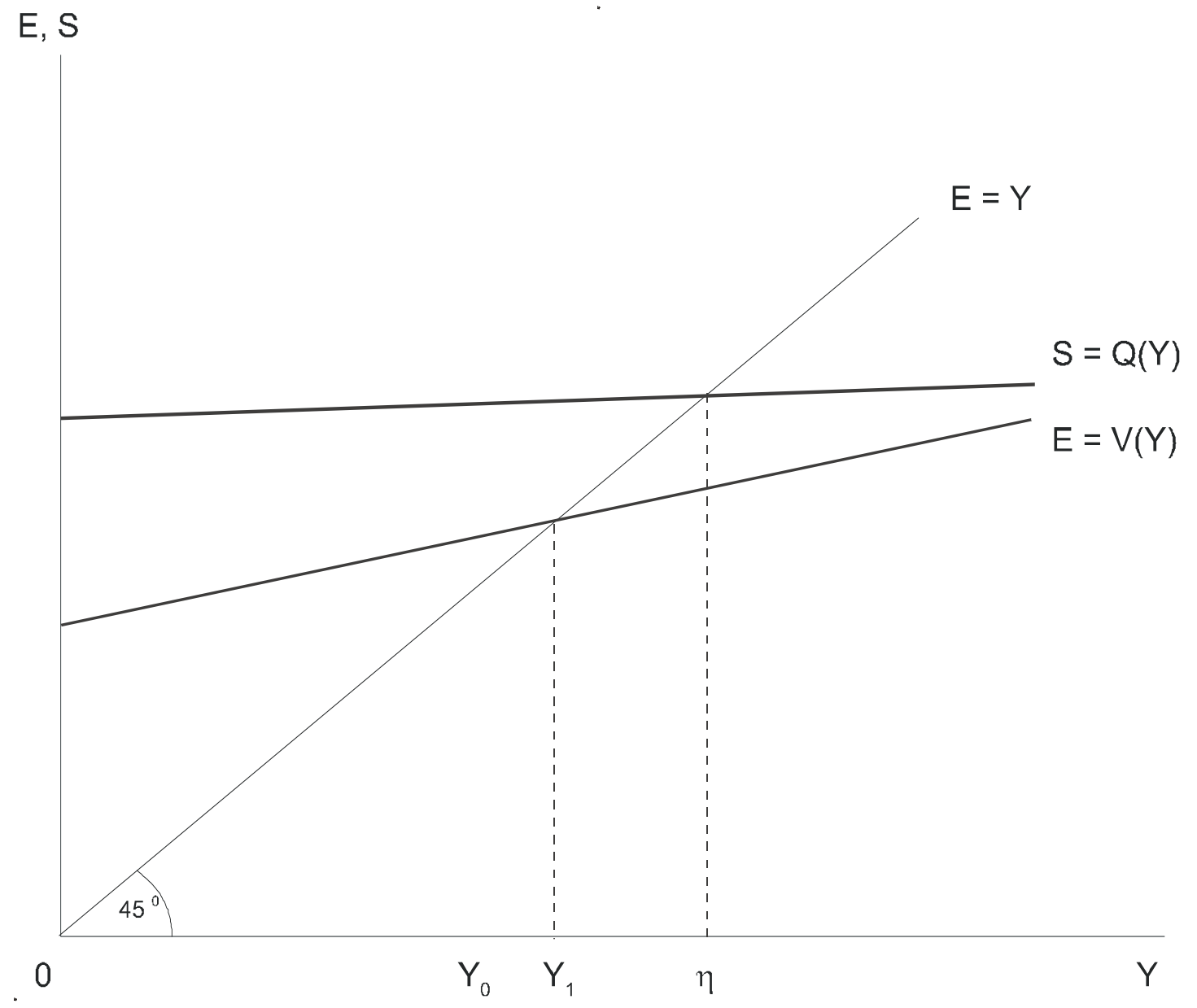

Figure 1: Patinkin’s “Desired Supply Function” (source: Patinkin [1949] 1981, p. 166) 
Y (Real income)

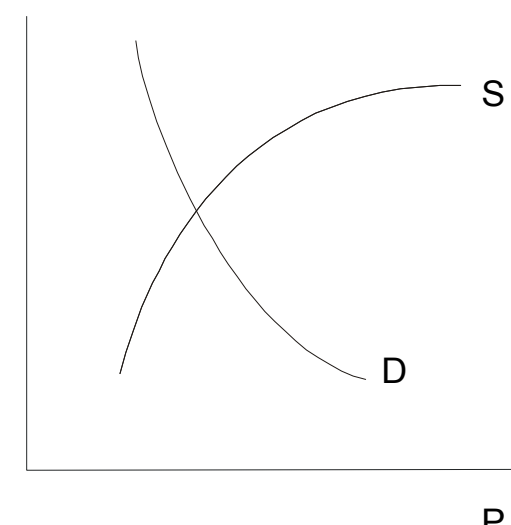

Money illusion in

both demand and supply sub-sets

A
Y (Real income)

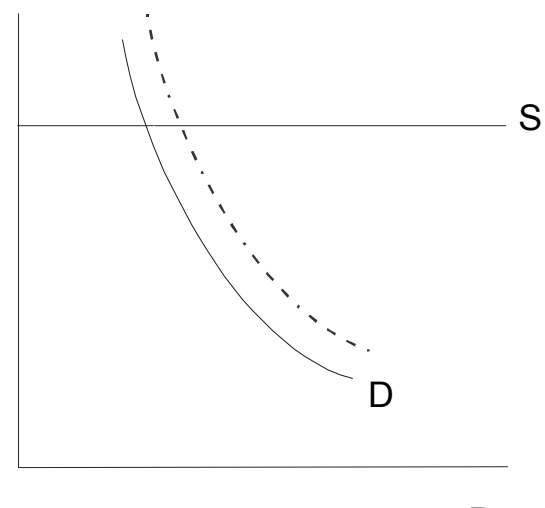

No money illusion in

supply sub-set

("Classical" case)

B
$\mathrm{Y}$ (Real income)

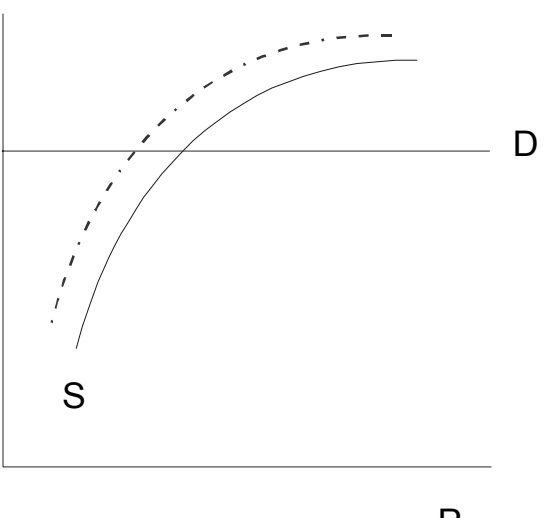

No money illusion in

demand sub-set

("Extreme Keynes")

Figure 2: "Determination of Price and Output When Labour Market is Free" (source: Marschak, 1951, p. 62) 


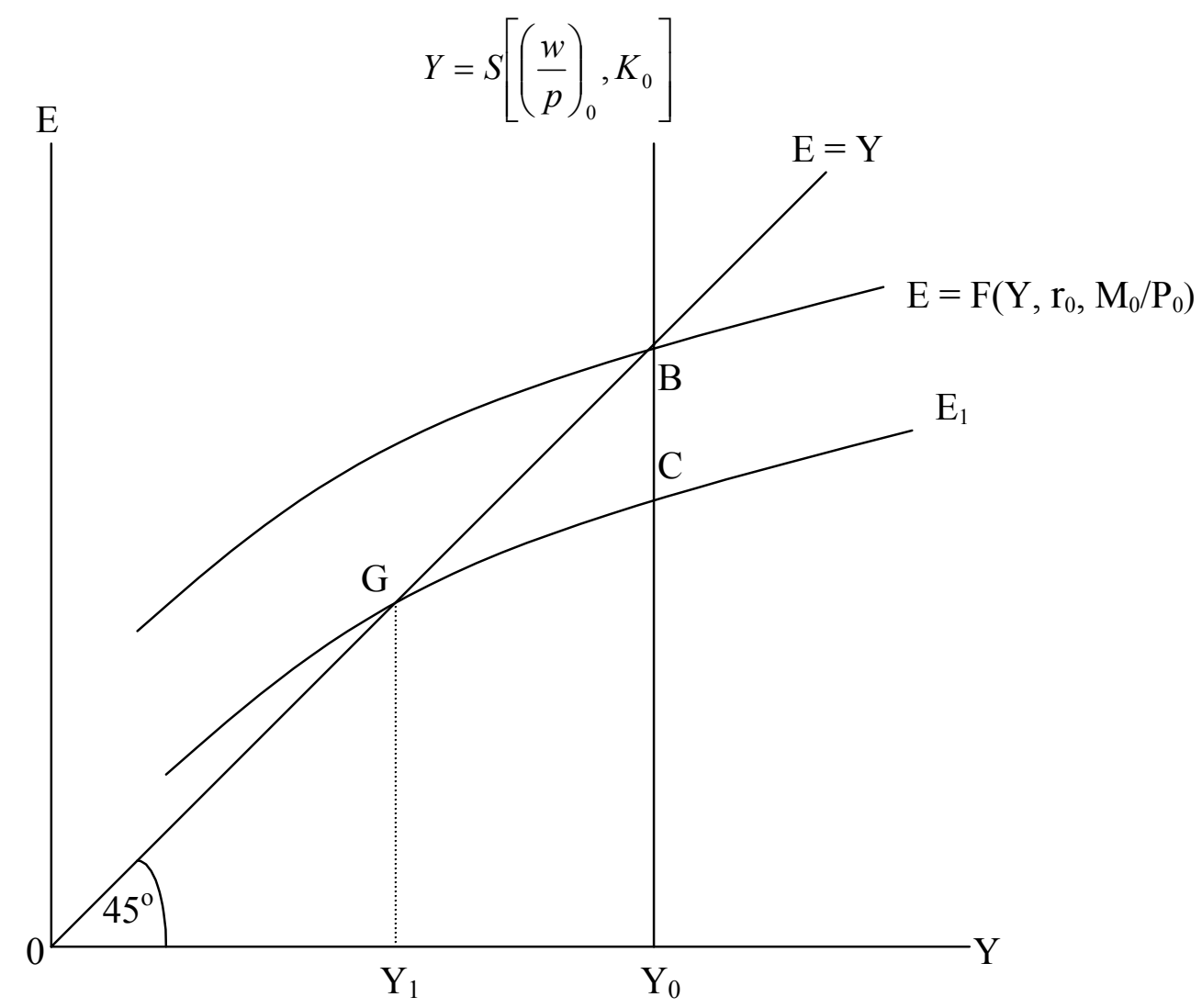

Figure 3: Demand Constraint and Disequilibrium (Source: Patinkin [1956] 1965, p. 317) 